\title{
Water-in-Oil-in-Water Double Emulsions as Protective Carriers for Sambucus nigra L. Coloring Systems
}

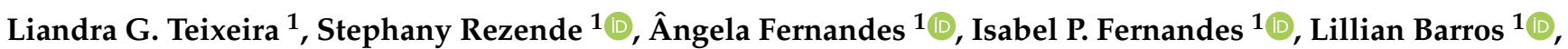 \\ João C. M. Barreira ${ }^{1, * \mathbb{C}}$, Fernanda V. Leimann ${ }^{2} \mathbb{D}$, Isabel C. F. R. Ferreira ${ }^{1} \mathbb{D}$ and Maria-Filomena Barreiro $1, * \mathbb{C}$ \\ 1 Centro de Investigação de Montanha (CIMO), Instituto Politécnico de Bragança, Campus de Santa Apolónia, \\ 5300-253 Bragança, Portugal; liandra@ipb.pt (L.G.T.); rezendes@ipb.pt (S.R.); afeitor@ipb.pt (Â.F.); \\ ipmf@ipb.pt (I.P.F.); lbarros@ipb.pt (L.B.); iferreira@ipb.pt (I.C.F.R.F.) \\ 2 Post-Graduation Program of Food Technology (PPGTA), Federal University of Technology-Paraná-UTFPR, \\ Campus Campo Mourão, Via Rosalina Maria dos Santos, 1233, Campo Mourão 87301-899, PR, Brazil; \\ fernandaleimann@utfpr.edu.br \\ * Correspondence: jbarreira@ipb.pt (J.C.M.B.); barreiro@ipb.pt (M.-F.B.)
}

check for updates

Citation: Teixeira, L.G.; Rezende, S.; Fernandes, Â.; Fernandes, I.P.; Barros, L.; Barreira, J.C.; Leimann, F.V.; Ferreira, I.C.; Barreiro, M.-F. Water-in-Oil-in-Water Double Emulsions as Protective Carriers for Sambucus nigra L. Coloring Systems. Molecules 2022, 27, 552. https:// doi.org/10.3390/molecules27020552

Academic Editor: Shilin Liu

Received: 17 December 2021

Accepted: 13 January 2022

Published: 16 January 2022

Publisher's Note: MDPI stays neutral with regard to jurisdictional claims in published maps and institutional affiliations.

Copyright: (C) 2022 by the authors. Licensee MDPI, Basel, Switzerland. This article is an open access article distributed under the terms and conditions of the Creative Commons Attribution (CC BY) license (https:// creativecommons.org/licenses/by/ $4.0 /)$.

\begin{abstract}
The use of natural colorants is needed to overcome consumer concerns regarding synthetic food colorants' safety. However, natural pigments have, in general, poor stability against environmental stresses such as temperature, ionic strength, moisture, light, and $\mathrm{pH}$, among others. In this work, water-in-oil-in-water $\left(\mathrm{W}_{1} / \mathrm{O} / \mathrm{W}_{2}\right)$ emulsions were used as protective carriers to improve color stability of a hydrophilic Sambucus nigra L. extract against $\mathrm{pH}$ changes. The chemical system comprised water and corn oil as the aqueous and oil phases, respectively, and polyglycerol polyricinoleate (PGPR), Tween 80, and gum Arabic as stabilizers. The primary emulsion was prepared using a $\mathrm{W}_{1} / \mathrm{O}$ ratio of $40 / 60(v / v)$. For the secondary emulsion, $\mathrm{W}_{1} / \mathrm{O} / \mathrm{W}_{2}$, different $\left(\mathrm{W}_{1} / \mathrm{O}\right) / \mathrm{W}_{2}$ ratios were tested with the $50 / 50(v / v)$ formulation presenting the best stability, being selected as the coloring system to test in food matrices of different $\mathrm{pH}$ : natural yogurt $(\mathrm{pH} 4.65)$, rice drink ( $\mathrm{pH}$ 6.01), cow milk ( $\mathrm{pH}$ 6.47), and soy drink ( $\mathrm{pH}$ 7.92). Compared to the direct use of the extract, the double emulsion solution gave rise to higher color stability with $\mathrm{pH}$ change and storage time, as corroborated by visual and statistical analysis.
\end{abstract}

Keywords: Sambucus nigra L. extract; natural colorants; color stability; double emulsions

\section{Introduction}

Sambucus nigra L. fruits, which belong to the elderberry species, have received significant attention as a source of dietary phytochemicals such as flavonoids and phenolic acids, not only for their richness but also due to their low price. These factors lead to an increased interest in their use as natural food additives, with their application being authorized by EFSA under the E163 code [1-4]. Sambucus nigra L. is traditionally used to produce pies, gelatins, ice creams, yoghurts, and beverages $[5,6]$.

In addition to their bioactivity, anthocyanins, the dominant component in elderberry species, are important coloring agents. Nevertheless, their use in the food industry can present limitations related to low stability to environmental stresses, such as temperature, ionic strength, moisture, light, presence of incompatible chemical and enzymatic compounds, and most of all, $\mathrm{pH}$ value. In fact, a color gradient from red to purple and blue is observed when $\mathrm{pH}$ changes from acidic to basic [3,7-9]. This behavior is a constraint for color standardization, i.e., to achieve the same color independently of the $\mathrm{pH}$ of the target food matrix. Moreover, $\mathrm{pH}$ changes occurring during the typical food processing conditions also make color tuning difficult. To overcome these drawbacks, technological solutions are required. Among them, encapsulation techniques such as spray-drying [10-12], freezedrying [13-15], liposomes [16-18], encapsulation in yeast cells [19], and emulsion-based technologies such as nanoemulsions [20,21] and double emulsions [22-26] can be cited. 
Double emulsions are systems formed by the dispersion of a primary emulsion into a continuous phase. In particular, water-in-oil-in-water $\left(\mathrm{W}_{1} / \mathrm{O} / \mathrm{W}_{2}\right)$ emulsions comprise the dispersion of a water-in-oil $\left(\mathrm{W}_{1} / \mathrm{O}\right)$ emulsion into an external aqueous phase $\left(\mathrm{W}_{2}\right)$. Double emulsions start to raise interest for the protection of hydrophilic compounds, including anthocyanins, being the stability of these systems decisive to guarantee their protection in the inner aqueous phase [27,28]. In this context, Eisinaite et al. [13] studied the encapsulation of a bioactive black chokeberry pomace extract focusing the stability of the double emulsion to storage and drying, reporting that the extract remained entrapped at high levels for the tested period of 60 days, and when subjected to freeze-drying processes to obtain powder-form products, this later stage was not practical to implement with the direct use of simple W/O emulsions. Regarding anthocyanins' color stability against $\mathrm{pH}$ variations, Liu et al. [29] studied the protection of a purple carrot extract by comparing its encapsulation in the inner and external aqueous phases of a $\mathrm{W}_{1} / \mathrm{O} / \mathrm{W}_{2}$. The authors pointed to the first strategy (incorporation in the inner aqueous phase) as the more suitable approach to protect hydrophilic colorants against external $\mathrm{pH}$ variations. In fact, in double emulsions, the oil phase offers the advantage of acting as a barrier between the two aqueous phases, protecting more effectively the incorporated compounds. Moreover, the use of the outer aqueous phase becomes less effective due to the direct exposition of the compounds to the external medium, similarly to the use of $\mathrm{O} / \mathrm{W}$ emulsions, which are systems not typically chosen to protect hydrophilic compounds. In summary, the application of double emulsions to protect the color of anthocyanins against $\mathrm{pH}$ variation is a promising strategy only scarcely addressed in the literature. To the best of our knowledge, the work of Liu et al. [29] is the only one addressing this problem. Considering the gathered achievements, the extension to other anthocyanin-based extracts and the proof of concept with real food matrices, not reported so far, is an important step to follow. Moreover, the reported studies, not only addressing the favorable protection of the compounds in the inner aqueous phase, but also indicating the high effectiveness to develop powder forms, highly desirable products for industry, reinforce motivation to proceed with these studies.

In the present work, $\mathrm{W}_{1} / \mathrm{O} / \mathrm{W}_{2}$ double emulsions containing Sambucus nigra $\mathrm{L}$. extract were produced and their efficacy to protect color against $\mathrm{pH}$ variations was evaluated. In a first step, four formulations of double emulsions were produced and characterized using optical microscopy and the creaming index monitored along time. The most stable formulation was then selected as a coloring agent to be incorporated into food matrices, chosen to cover a wide range of $\mathrm{pH}$ values, and the color was evaluated along a storage period of 7 days using two storage conditions (room and refrigerated temperature). The performance of the developed solution was compared with the use of the free extract. The obtained data were analyzed using a two-way analysis of variance (ANOVA). Considering the presence of oil in the double emulsion, the impact on the final food product was evaluated by determining their influence on the final fatty acid composition (SFA, MUFA, PUFA). Future study involving the use of the developed solutions is recommended in light of the presented advantages and disadvantages.

\section{Results and Discussion}

\subsection{Obtainment of the Double Emulsions Coloring System}

All the tested formulations, which were prepared using a primary emulsion with a $W_{1} / O$ ratio of $40 / 60$ and $\left(W_{1} / O\right) / W_{2}$ ratios of $20 / 80,30 / 70,40 / 60$, and 50/50 in the secondary emulsion, led to the formation of double emulsions characterized by the typical morphological pattern of tiny aqueous droplets inside oil droplets dispersed in a second aqueous phase, as described in the literature [30-32], and perceived in the acquired images (Figure 1). This morphology, characterized by an inner aqueous phase surrounded by an oil barrier, conforms a protective system for hydrophilic compounds against external aqueous phase environmental stresses, as it is in the case of anthocyanins coloring systems, which present instability to external $\mathrm{pH}[26,33]$. For comparison purposes, a detail of the primary emulsion using the same magnification was added to each image of Figure 1. 

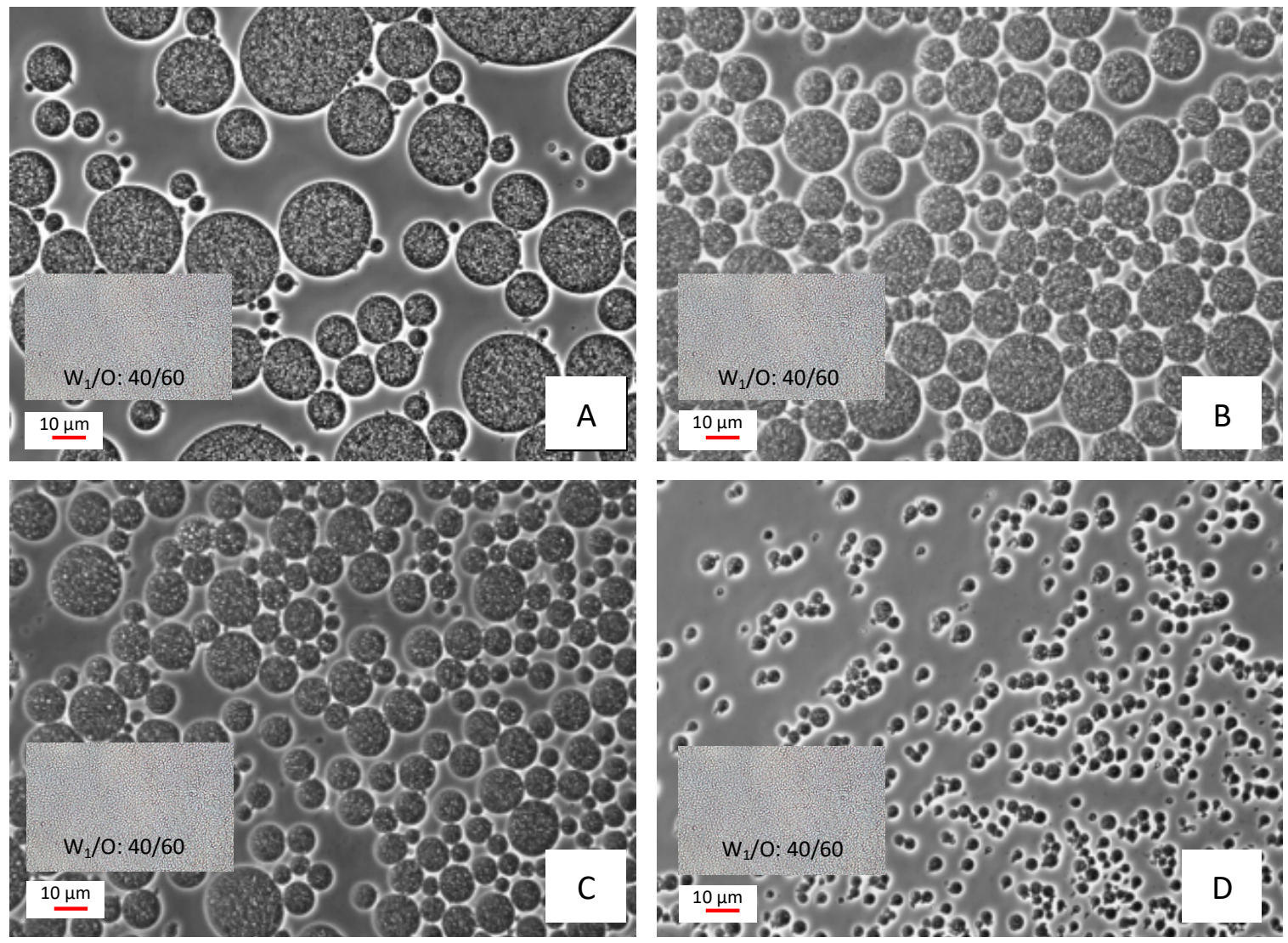

Figure 1. Morphology and size of the prepared double emulsions: 20/80 (A), 30/70 (B), 40/60 (C), and 50/50 (D) formulations. Each image includes a detail of the $40 / 60$ primary emulsion using the same magnification; $400 \times$ magnification.

Among the tested double emulsions, the 50/50 formulation presented the smaller droplet size right after formation $(<5 \mu \mathrm{m})$ (Figure 1). Moreover, this formulation was the most viscous, as perceived by visual inspection, a fact that could be related to the higher amount of the $\mathrm{W}_{1} / \mathrm{O}$ primary emulsion used (increase in oil content). The higher viscosity favors emulsion stability, resulting in a better protection of the elderberry extract for this formulation [34]. This effect was corroborated by the performed CI (\%) measurements (Table 1), which indicated a lower cream index (CI) value for the 50/50 formulation, when compared to the other tested ratios, for all the evaluated times. Considering the obtained results, the formulation 50/50 was chosen as the coloring system to be tested in food matrices.

Table 1. Creaming index evolution along 20 days for the tested formulations $(20 / 80,30 / 70,40 / 60$, and 50/50).

\begin{tabular}{ccccc}
\hline \multirow{2}{*}{$\begin{array}{c}\text { Time } \\
\text { (Days) }\end{array}$} & $\mathbf{4}$ Cream Index (CI, \%) \\
\cline { 2 - 5 } & $\mathbf{2 0 / 8 0}$ & $\mathbf{3 0 / 7 0}$ & $\mathbf{4 0 / 6 0}$ & $\mathbf{5 0 / 5 0}$ \\
\hline 0 & 68 & 16 & 0 & 0 \\
5 & 72 & 48 & 25 & 0 \\
10 & 73 & 54 & 37 & 12 \\
20 & 74 & 56 & 44 & 20 \\
\hline
\end{tabular}

\subsection{Testing of the Double Emulsion Coloring System}

The application test was carried out by comparing the use of the pure extract with the chosen double emulsion $(50 / 50)$ in the selected food matrices holding different $\mathrm{pH}$ : natural yogurt ( $\mathrm{pH} 4.65$ ), rice drink ( $\mathrm{pH}$ 6.01), cow milk ( $\mathrm{pH}$ 6.47), and soy drink ( $\mathrm{pH} 7.92)$. The 
color analysis was performed under two storage conditions, namely $23^{\circ} \mathrm{C}$ (room temperature) and $4{ }^{\circ} \mathrm{C}$ (refrigeration temperature). The color evaluation was done immediately after incorporation and after 3 and 7 days. The photographic record is shown in Figure 2.

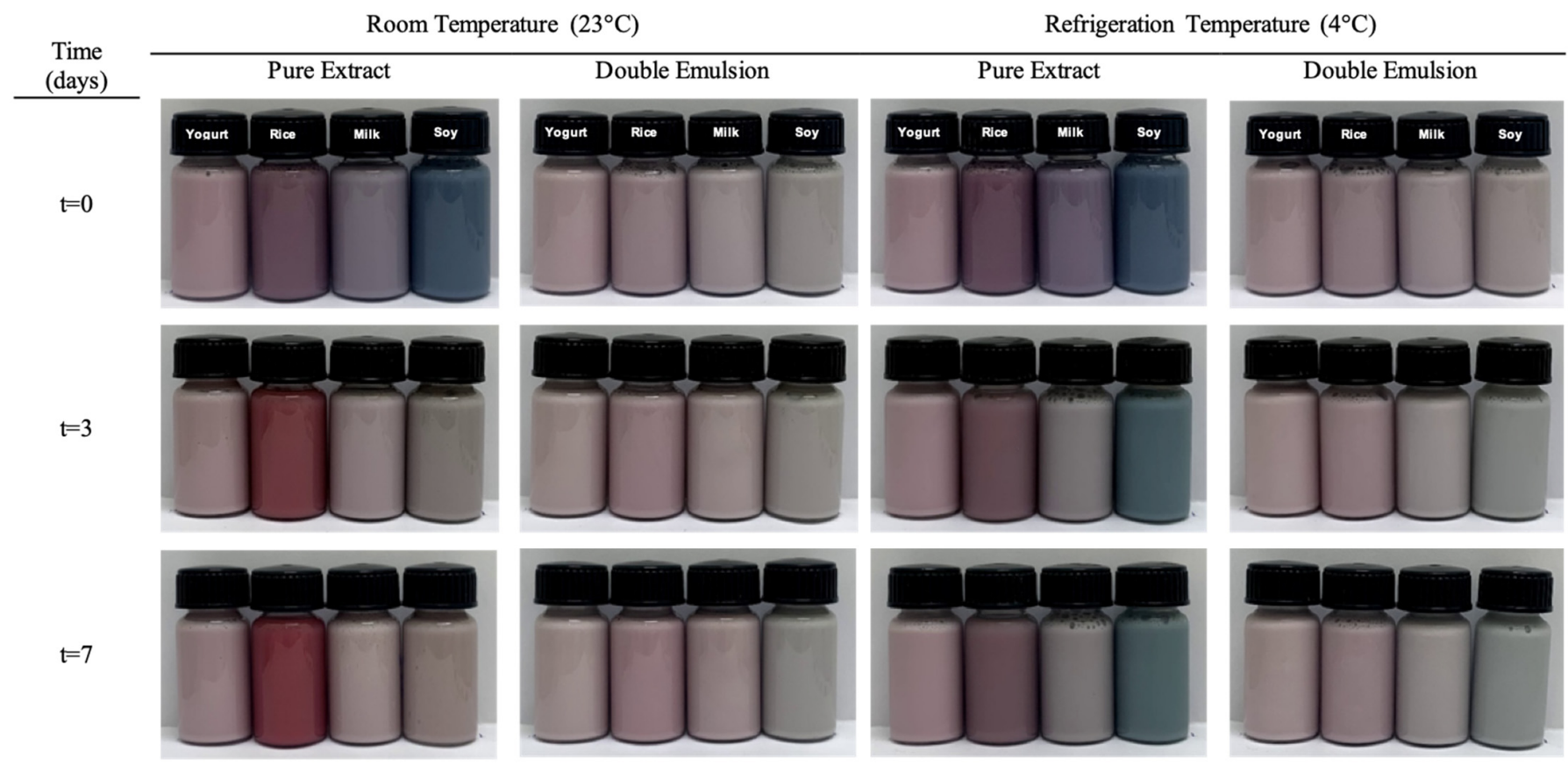

Figure 2. Photographic record of the food drinks yogurt ( $\mathrm{pH} 4.65)$, rice ( $\mathrm{pH}$ 6.01), milk ( $\mathrm{pH}$ 6.47), and soy ( $\mathrm{pH} 7.92$ ) added with the free extract and the coloring emulsion as a function of time and temperature (temperature of $4{ }^{\circ} \mathrm{C}$ and $23^{\circ} \mathrm{C}$ and time of 0,3 and 7 days).

Considering the studied experimental conditions, three variability sources were firstly selected: formulation type (FT), storage time (ST), and storage temperature (STe). There was a possibility of performing a three-way ANOVA, which examines the statistical differences induced by each factor individually, as well as the interactions FT $\times$ ST, FT $\times$ Ste, ST $\times$ Ste, and FT $\times$ ST $\times$ Ste. However, this type of analysis often leads to puzzling results, hindering meaningful conclusions. Therefore, different combinations of two factors were assayed $(\mathrm{FT} \times \mathrm{ST}, \mathrm{FT} \times \mathrm{STe}$ and $\mathrm{ST} \times \mathrm{STe})$, verifying that STe was the factor inducing the least variability in the results. Accordingly, the FT and ST were selected as the factors to be studied in the 2-way ANOVA. To prevent the natural variability of color parameters among the four assayed beverages concealing any difference induced by the studied factors, each food product was studied individually.

When a two-way ANOVA is applied, it is necessary to verify if the interaction $(\mathrm{FT} \times \mathrm{ST})$ between the two considered factors is significant $(p<0.001)$. Likewise, the values presented for each level (control, 3 days, and 7 days in the case of ST; double emulsion and extract for FT) of a determining factor are obtained by the mean values of all levels of the second factor, which sometimes leads to high standard deviation values; however, these values should not be regarded as precision indicators, but instead as a primary indication of the variability induced by the non-fixed factor.

Besides measuring the values for $\mathrm{L}^{*}, \mathrm{a}^{*}$, and $\mathrm{b}^{*}$, the corresponding $\triangle \mathrm{E}$ were also calculated through Equation (2) (mentioned in 4.3). The color parameters measured for samples stored at $4{ }^{\circ} \mathrm{C}$ are described in Table 2, and the ones measure for $23^{\circ} \mathrm{C}$ described in Table 3. As can be observed, the interaction among factors was significant in all cases, not allowing classification of the values according to the Tukey (or Tamhane's T2) test. Nonetheless, it is evident that, independently of the food product, FT had a much more significant effect ( $p<0.05$ in all cases except a * in milk) on color parameters than ST, which showed a significant effect only over a * value in milk and soy, tendentially higher 
in non-stored samples, as indicated by the estimated marginal means (EMM) plots (nonprovided data).

Table 2. Effect of different storage time and formulation type on the colorimetric parameters of the tested beverages stored at $4{ }^{\circ} \mathrm{C}$.

\begin{tabular}{|c|c|c|c|c|c|}
\hline & & $\mathbf{L}^{*}$ & $a^{*}$ & $\mathbf{b}^{*}$ & $\Delta \mathrm{E}$ \\
\hline \multicolumn{6}{|c|}{ Yogurt } \\
\hline \multicolumn{2}{|c|}{ Control } & $81.03 \pm 0.01$ & $-2.29 \pm 0.01$ & $7.49 \pm 0.01$ & - \\
\hline Storage time (ST) & $\begin{array}{l}0 \text { days } \\
3 \text { days } \\
7 \text { days }\end{array}$ & $\begin{array}{l}66 \pm 2 \\
66 \pm 2 \\
66 \pm 2\end{array}$ & $\begin{array}{l}10 \pm 1 \\
9 \pm 1 \\
9 \pm 1\end{array}$ & $\begin{array}{l}0.5 \pm 0.5 \\
0.7 \pm 0.6 \\
0.8 \pm 0.6\end{array}$ & $\begin{array}{l}21 \pm 2 \\
20 \pm 3 \\
20 \pm 3\end{array}$ \\
\hline \multicolumn{2}{|c|}{$p$-value ${ }^{\mathrm{A}}(\mathrm{n}=6)$} & 0.908 & 0.426 & 0.806 & 0.782 \\
\hline Formulation type (FT) & $\begin{array}{c}\text { Extract } \\
\text { Double emulsion }\end{array}$ & $\begin{array}{l}64.1 \pm 0.2 \\
68.2 \pm 0.3\end{array}$ & $\begin{array}{l}10.5 \pm 0.3 \\
8.3 \pm 0.5\end{array}$ & $\begin{array}{l}0.1 \pm 0.1 \\
1.2 \pm 0.1\end{array}$ & $\begin{array}{l}22.5 \pm 0.4 \\
17.8 \pm 0.5\end{array}$ \\
\hline \multicolumn{2}{|c|}{$p$-value ${ }^{B}(n=9)$} & $<0.001$ & $<0.001$ & $<0.001$ & $<0.001$ \\
\hline \multicolumn{2}{|c|}{$\mathrm{ST} \times \mathrm{FT} p$-value ${ }^{\mathrm{C}}(\mathrm{n}=18)$} & $<0.001$ & $<0.001$ & $<0.001$ & $<0.001$ \\
\hline \multicolumn{6}{|c|}{ Rice } \\
\hline \multicolumn{2}{|c|}{ Control } & $61.97 \pm 0.01$ & $-1.28 \pm 0.01$ & $-3.95 \pm 0.01$ & - \\
\hline Storage time (ST) & $\begin{array}{l}0 \text { days } \\
3 \text { days } \\
7 \text { days } \\
\end{array}$ & $\begin{array}{l}52 \pm 11 \\
53 \pm 10 \\
53 \pm 10\end{array}$ & $\begin{array}{l}9.8 \pm 0.5 \\
9.4 \pm 0.1 \\
9.3 \pm 0.1\end{array}$ & $\begin{array}{l}-1 \pm 1 \\
-1 \pm 1 \\
-1 \pm 1\end{array}$ & $\begin{array}{l}17 \pm 6 \\
16 \pm 5 \\
16 \pm 5 \\
\end{array}$ \\
\hline \multicolumn{2}{|c|}{$p$-value ${ }^{\mathrm{A}}(\mathrm{n}=6)$} & 0.987 & 0.147 & 0.504 & 0.945 \\
\hline Formulation type (FT) & $\begin{array}{c}\text { Extract } \\
\text { Double emulsion }\end{array}$ & $\begin{array}{l}43 \pm 1 \\
62 \pm 1\end{array}$ & $\begin{array}{l}9.8 \pm 0.5 \\
9.3 \pm 0.1 \\
\end{array}$ & $\begin{array}{l}-1 \pm 1 \\
0.0 \pm 0.1\end{array}$ & $\begin{array}{c}22 \pm 1 \\
11 \pm 1 \\
\end{array}$ \\
\hline \multicolumn{2}{|c|}{$p$-value ${ }^{B}(n=9)$} & $<0.001$ & 0.040 & $<0.001$ & $<0.001$ \\
\hline \multicolumn{2}{|c|}{$\mathrm{ST} \times \mathrm{FT} p$-value ${ }^{\mathrm{C}}(\mathrm{n}=18)$} & $<0.001$ & $<0.001$ & $<0.001$ & $<0.001$ \\
\hline \multicolumn{6}{|c|}{ Milk } \\
\hline \multicolumn{2}{|c|}{ Control } & $77.88 \pm 0.01$ & $-3.60 \pm 0.01$ & $5.03 \pm 0.01$ & - \\
\hline Storage time(ST) & $\begin{array}{l}0 \text { days } \\
3 \text { days } \\
7 \text { days } \\
\end{array}$ & $\begin{array}{l}59 \pm 9 \\
62 \pm 5 \\
62 \pm 5 \\
\end{array}$ & $\begin{array}{l}8 \pm 2 \\
5 \pm 1 \\
5 \pm 1\end{array}$ & $\begin{array}{l}-3 \pm 3 \\
-1 \pm 1 \\
-1 \pm 1\end{array}$ & $\begin{array}{l}24 \pm 9 \\
19 \pm 5 \\
19 \pm 4 \\
\end{array}$ \\
\hline \multicolumn{2}{|c|}{$p$-value ${ }^{A}(n=6)$} & 0.665 & 0.001 & 0.199 & 0.399 \\
\hline $\begin{array}{l}\text { Formulation type } \\
\text { (FT) }\end{array}$ & $\begin{array}{c}\text { Extract } \\
\text { Double emulsion }\end{array}$ & $\begin{array}{l}55 \pm 3 \\
67 \pm 1\end{array}$ & $\begin{array}{l}7 \pm 2 \\
5 \pm 1\end{array}$ & $\begin{array}{c}-3 \pm 2 \\
0.1 \pm 0.1\end{array}$ & $\begin{array}{l}26 \pm 4 \\
15 \pm 1\end{array}$ \\
\hline Valor de $p$-v & $n=9)$ & $<0.001$ & 0.060 & 0.001 & $<0.001$ \\
\hline \multicolumn{2}{|c|}{$\mathrm{ST} \times$ FT $p$-value ${ }^{\mathrm{C}}(\mathrm{n}=18)$} & $<0.001$ & $<0.001$ & $<0.001$ & $<0.001$ \\
\hline \multicolumn{6}{|c|}{ Soy } \\
\hline \multicolumn{2}{|c|}{ Control } & $71.64 \pm 0.01$ & $-3.23 \pm 0.01$ & $10.92 \pm 0.01$ & - \\
\hline Storage time (ST) & $\begin{array}{l}0 \text { days } \\
3 \text { days } \\
7 \text { days } \\
\end{array}$ & $\begin{array}{c}56 \pm 13 \\
57 \pm 9 \\
57 \pm 8\end{array}$ & $\begin{array}{c}2 \pm 2 \\
-1 \pm 1 \\
-1 \pm 1\end{array}$ & $\begin{array}{l}-4 \pm 6 \\
-3 \pm 3 \\
-2 \pm 2\end{array}$ & $\begin{array}{c}24 \pm 12 \\
21 \pm 8 \\
21 \pm 7\end{array}$ \\
\hline \multicolumn{2}{|c|}{$p$-value ${ }^{\mathrm{A}}(\mathrm{n}=6)$} & 0.979 & 0.021 & 0.772 & 0.845 \\
\hline Formulation type (FT) & $\begin{array}{c}\text { Extract } \\
\text { Double emulsion }\end{array}$ & $\begin{array}{l}47 \pm 3 \\
66 \pm 2 \\
\end{array}$ & $\begin{array}{l}-1 \pm 1 \\
2 \pm 1\end{array}$ & $\begin{array}{c}-7 \pm 2 \\
1 \pm 1\end{array}$ & $\begin{array}{l}30 \pm 4 \\
13 \pm 1\end{array}$ \\
\hline \multicolumn{2}{|c|}{$p$-value ${ }^{B}(n=9)$} & $<0.001$ & $<0.001$ & $<0.001$ & $<0.001$ \\
\hline \multicolumn{2}{|c|}{$\mathrm{ST} \times \mathrm{FT} p$-value ${ }^{\mathrm{C}}(\mathrm{n}=18)$} & $<0.001$ & $<0.001$ & $<0.001$ & $<0.001$ \\
\hline
\end{tabular}

${ }^{\mathrm{A}} p$-value $<0.050$ indicates a significant difference in that parameter for at least one storage time. ${ }^{\mathrm{B}} p$-value $<0.050$ indicates a significant difference in that parameter among both formulation types. ${ }^{\mathrm{C}} p$-value $<0.050$ indicates a significant interaction among the two factors (ST and FT), not allowing to present the statistical classification from the multiple comparison tests. 
Table 3. Effect of different storage time and formulation type on the colorimetric parameters of the tested beverages stored at $23^{\circ} \mathrm{C}$.

\begin{tabular}{|c|c|c|c|c|c|}
\hline & & $L^{*}$ & $a^{*}$ & $\mathbf{b}^{*}$ & $\Delta \mathrm{E}$ \\
\hline \multicolumn{6}{|c|}{ Yogurt } \\
\hline \multicolumn{2}{|c|}{ Control } & $81.03 \pm 0.01$ & $-2.29 \pm 0.01$ & $7.49 \pm 0.01$ & - \\
\hline \multirow{3}{*}{ Storage time (ST) } & 0 days & $66 \pm 2$ & $10 \pm 1$ & $0.5 \pm 0.5$ & $21 \pm 2$ \\
\hline & 3 days & $66 \pm 2$ & $10 \pm 2$ & $1.1 \pm 0.3$ & $20 \pm 3$ \\
\hline & 7 days & $66 \pm 3$ & $10 \pm 3$ & $2.0 \pm 0.3$ & $20 \pm 3$ \\
\hline \multicolumn{2}{|c|}{$p$-value ${ }^{A}(n=6)$} & 0.915 & 0.994 & $<0.001$ & 0.913 \\
\hline \multirow{2}{*}{ Formulation type (FT) } & Extract & $63.9 \pm 0.2$ & $11.5 \pm 0.5$ & $1 \pm 1$ & $23.0 \pm 0.2$ \\
\hline & Double emulsion & $68.4 \pm 0.4$ & $7.9 \pm 0.5$ & $1.4 \pm 0.3$ & $17.4 \pm 0.5$ \\
\hline \multicolumn{2}{|c|}{$p$-value ${ }^{B}(\mathrm{n}=9)$} & $<0.001$ & $<0.001$ & 0.325 & $<0.001$ \\
\hline \multicolumn{2}{|c|}{$\mathrm{ST} \times \mathrm{FT} p$-value ${ }^{\mathrm{C}}(\mathrm{n}=18)$} & $<0.001$ & $<0.001$ & $<0.001$ & $<0.001$ \\
\hline \multicolumn{6}{|c|}{ Rice } \\
\hline \multicolumn{2}{|c|}{ Control } & $61.97 \pm 0.01$ & $-1.28 \pm 0.01$ & $-3.95 \pm 0.01$ & - \\
\hline \multirow{3}{*}{ Storage time (ST) } & 0 days & $52 \pm 11$ & $10 \pm 1$ & $-1 \pm 1$ & $17 \pm 6$ \\
\hline & 3 days & $49 \pm 14$ & $15 \pm 6$ & $2 \pm 2$ & $23 \pm 12$ \\
\hline & 7 days & $47 \pm 16$ & $16 \pm 5$ & $3 \pm 3$ & $26 \pm 14$ \\
\hline \multicolumn{2}{|c|}{$p$-value ${ }^{\mathrm{A}}(\mathrm{n}=6)$} & 0.819 & 0.061 & 0.005 & 0.403 \\
\hline \multirow{2}{*}{ Formulation type (FT) } & Extract & $37 \pm 4$ & $17 \pm 5$ & $3 \pm 4$ & $32 \pm 7$ \\
\hline & Double emulsion & $62 \pm 1$ & $10 \pm 1$ & $0.4 \pm 0.4$ & $12 \pm 1$ \\
\hline \multicolumn{2}{|c|}{$p$-value ${ }^{B}(n=9)$} & $<0.001$ & 0.005 & 0.124 & $<0.001$ \\
\hline \multicolumn{2}{|c|}{$\mathrm{ST} \times$ FT $p$-value ${ }^{\mathrm{C}}(\mathrm{n}=18)$} & $<0.001$ & $<0.001$ & $<0.001$ & $<0.001$ \\
\hline \multicolumn{6}{|c|}{ Milk } \\
\hline \multicolumn{2}{|c|}{ Control } & $77.88 \pm 0.01$ & $-3.60 \pm 0.01$ & $5.03 \pm 0.01$ & - \\
\hline \multirow{3}{*}{ Storage time (ST) } & 0 days & $61 \pm 6$ & $6 \pm 1$ & $-2 \pm 2$ & $21 \pm 6$ \\
\hline & 3 days & $64 \pm 3$ & $7 \pm 1$ & $1 \pm 1$ & $18 \pm 3$ \\
\hline & 7 days & $65 \pm 1$ & $7 \pm 1$ & $1 \pm 1$ & $17 \pm 1$ \\
\hline \multicolumn{2}{|c|}{$p$-value ${ }^{A}(n=6)$} & 0.281 & 0.137 & 0.001 & 0.264 \\
\hline \multirow{2}{*}{ Formulation type (FT) } & Extract & $60 \pm 4$ & $7 \pm 1$ & $-1 \pm 2$ & $22 \pm 4$ \\
\hline & Double emulsion & $67 \pm 1$ & $6 \pm 1$ & $1 \pm 1$ & $16 \pm 1$ \\
\hline \multicolumn{2}{|c|}{$p$-value ${ }^{B}(\mathrm{n}=9)$} & 0.001 & 0.087 & 0.097 & 0.001 \\
\hline \multicolumn{2}{|c|}{$\mathrm{ST} \times \mathrm{FT} p$-value ${ }^{\mathrm{C}}(\mathrm{n}=18)$} & $<0.001$ & $<0.001$ & $<0.001$ & $<0.001$ \\
\hline \multicolumn{6}{|c|}{ Soy } \\
\hline \multicolumn{2}{|c|}{ Control } & $71.64 \pm 0.01$ & $-3.23 \pm 0.01$ & $10.92 \pm 0.01$ & - \\
\hline \multirow{3}{*}{ Storage time (ST) } & 0 days & $56 \pm 13$ & $2 \pm 1$ & $-4 \pm 5$ & $23 \pm 12$ \\
\hline & 3 days & $62 \pm 5$ & $3 \pm 1$ & $1 \pm 1$ & $15 \pm 3$ \\
\hline & 7 days & $64 \pm 3$ & $5 \pm 2$ & $2 \pm 1$ & $15 \pm 2$ \\
\hline \multicolumn{2}{|c|}{$p$-value ${ }^{\mathrm{A}}(\mathrm{n}=6)$} & 0.198 & 0.009 & 0.012 & 0.098 \\
\hline \multirow{2}{*}{ Formulation type (FT) } & Extract & $54 \pm 8$ & $3 \pm 3$ & $-2 \pm 5$ & $23 \pm 8$ \\
\hline & Double emulsion & $67 \pm 1$ & $3 \pm 1$ & $1 \pm 1$ & $13 \pm 1$ \\
\hline$p$-value & & 0.001 & 0.496 & 0.127 & 0.005 \\
\hline $\mathrm{ST} \times \mathrm{FT} p$-va & $=18)$ & $<0.001$ & $<0.001$ & $<0.001$ & $<0.001$ \\
\hline
\end{tabular}


In the FT effect, all beverages showed higher $L^{*}$ and $b$ * values when added with the double emulsion, instead of the extract itself. In turn, $a^{*}$ values were lower (except for soy) in samples added to the double emulsion. Despite these differences, the parameter to be considered with higher relevance is $\Delta \mathrm{E}$, which represents the global difference between two colors. In this sense, and in the present case, higher $\Delta \mathrm{E}$ values should be considered preferable since this result could be an indicator of a higher coloring capacity. When looking at Table 2, it is evident that $\Delta \mathrm{E}$ is higher when the extract is added directly, which, at first sight, would indicate this as the best coloring solution. Nonetheless, it is also evident from Table 2 that the parameter with the highest contribution to the $\Delta \mathrm{E}$ value is $\mathrm{L} *$. Therefore, the values calculated for $\Delta \mathrm{E}$ indicate that the beverages containing the double emulsion are brighter than those prepared with the direct addition of the extract, i.e., the double emulsion allowed keeping the $\mathrm{L}^{*}$ values of the control samples in a greater extent, showing its higher suitability as a coloring agent to be used in these specific beverages.

The results were similar, despite showing some differences, when samples were stored at $23{ }^{\circ} \mathrm{C}$ (Table 3), instead of $4{ }^{\circ} \mathrm{C}$ (Table 2). The effect of FT was, again, more pronounced, but the values of $b^{*}$ did not show significant differences for this factor. On the other hand, ST exerted a significant effect on more occasions when compared with the results obtained from the $4{ }^{\circ} \mathrm{C}$ stored samples, particularly for $\mathrm{b}^{*}$ values in all beverages and $\mathrm{a}{ }^{*}$ values in soy. Nevertheless, the results for $\Delta \mathrm{E}$ values were highly similar, showing one more time that the greatest difference in color parameters was registered for $\mathrm{L}^{*}$ values (better kept again when using the double emulsion).

After studying each beverage separately, a linear discriminant analysis was performed to verify the differences among different FT from a global perspective. As may be concluded from Figure 3, function 1 mostly separated the markers corresponding to the control samples from those added with any type of coloring formulation, mainly due to the lower $a^{*}$ values in the control samples. Furthermore, there is good separation among markers corresponding to samples added with double emulsion and those prepared by adding the extract directly. This separation resulted specifically from function 2, which placed double emulsion markers in the negative side of the axis and those corresponding to the extract added directly in the positive side of the same axis. According to the correlation coefficients, this function was more highly correlated with $\Delta \mathrm{E}$ values, which were lower in all beverages prepared with double emulsion. This result corroborates the assumption indicating that $\Delta \mathrm{E}$ was the parameter with the highest differences among both types of formulation.

\subsection{Critical Analysis of the Applicability of the Double Emulsion Coloring System}

The efficacy of the developed solution, which justifies the lower color variability with $\mathrm{pH}$ for the samples added with the double emulsion, compared to the ones added with the free extract, relies on the protection conferred by the oil barrier positioned between the inner and outer aqueous phases. For the developed formulation, it constitutes 30\% $(v / v)$ of the $50 / 50$ emulsion and approximately $10 \%(v / v)$ of the colored food, which impacts the proximal composition of the final products, as can be seen in Table 4, where a comparison between the base drinks and corresponding colored counterparts is presented. In general, a non-significant impact can be perceived when adding the free extract, whereas a generally significant impact, particularly for lipids, can be noted when the emulsion is added, corroborating that the used oil amount has a high impact in the final food products. This constraint can be circumvented by optimizing other formulations with lower oil content or using higher colorant concentrations in the inner aqueous phase. Additionally, colorants with high coloring power might result in improved solutions. Even so, the advantages of the developed strategy over the use of the free extract were demonstrated with a proof of concept using real food matrices. 


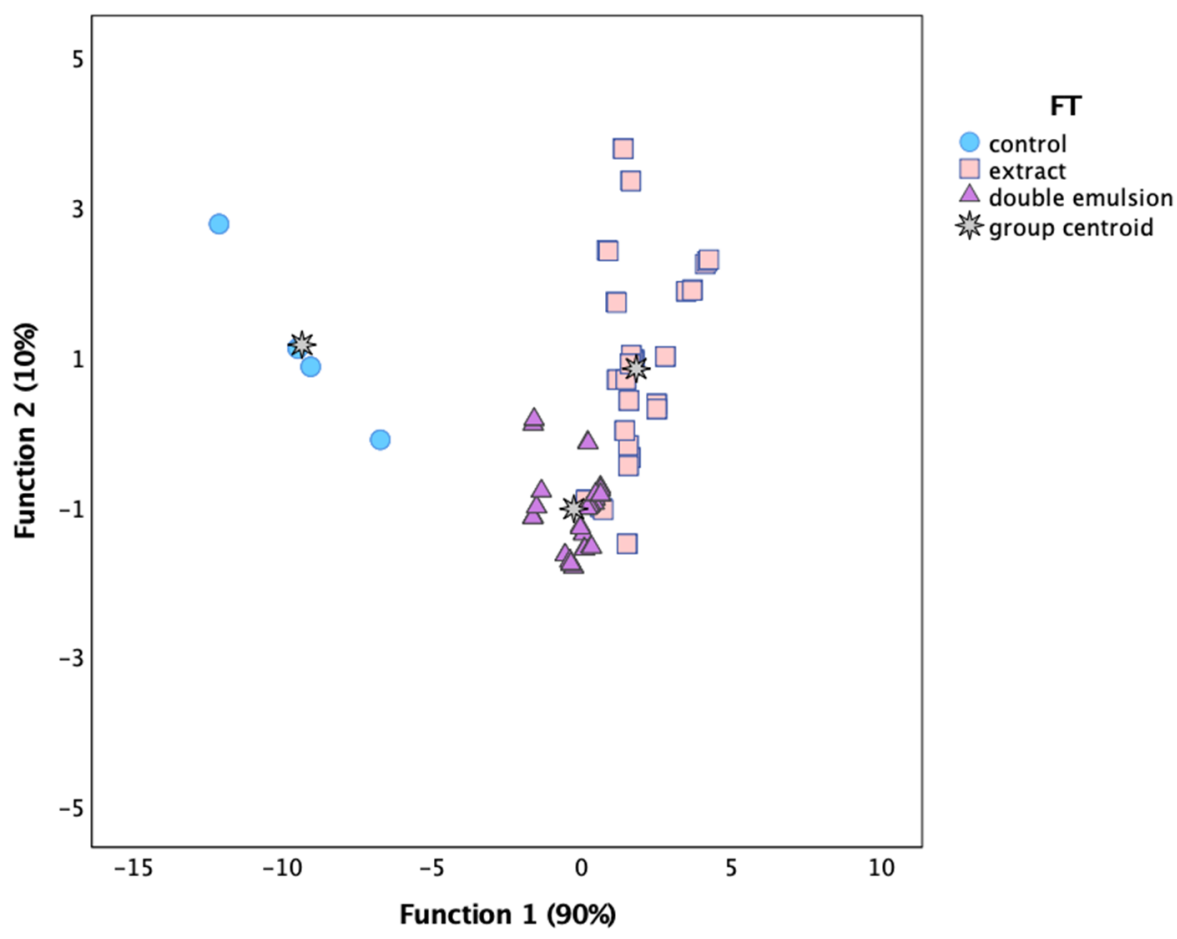

Figure 3. Three-dimensional distribution of FT markers according to the discriminant functions coefficients defined from the colorimetric parameters.

Table 4. Proximal composition of the base drinks (Yogurt, Rice, Milk, and Soy) and corresponding colored counterparts added with extract (Extract) and double emulsion (Double Emulsion). The values are expressed in $\mathrm{g} / 100 \mathrm{~mL}$.

\begin{tabular}{cccccc}
\hline Sample & Moisture & Ashes & Proteins & Lipids & Carbohydrates \\
\hline Yogurt (control) & $85.1 \pm 0.8^{\mathrm{a}}$ & $0.77 \pm 0.03^{\mathrm{a}}$ & $7.89 \pm 0.08^{\mathrm{a}}$ & $0.445 \pm 0.001^{\mathrm{b}}$ & $5.8 \pm 0.5^{\mathrm{a}}$ \\
Extract & $85.48 \pm 0.04^{\mathrm{a}}$ & $0.77 \pm 0.02^{\mathrm{a}}$ & $7.77 \pm 0.02^{\mathrm{a}}$ & $0.46 \pm 0.01^{\mathrm{b}}$ & $5.52 \pm 0.02^{\mathrm{a}}$ \\
Double emulsion & $78.5 \pm 0.2^{\mathrm{b}}$ & $0.74 \pm 0.01^{\mathrm{b}}$ & $5.2 \pm 0.2^{\mathrm{b}}$ & $10.71 \pm 0.04^{\mathrm{a}}$ & $4.9 \pm 0.3^{\mathrm{c}}$ \\
\hline Rice (control) & $86.9 \pm 0.3^{\mathrm{b}}$ & $0.15 \pm 0.01^{\mathrm{a}}$ & $1.0 \pm 0.1^{\mathrm{a}}$ & $1.01 \pm 0.05^{\mathrm{b}}$ & $11.0 \pm 0.2^{\mathrm{a}}$ \\
Extract & $87.40 \pm 0.07^{\mathrm{a}}$ & $0.119 \pm 0.003^{\mathrm{c}}$ & $1.03 \pm 0.03^{\mathrm{a}}$ & $0.97 \pm 0.03^{\mathrm{b}}$ & $10.48^{\mathrm{a}} \pm 0.01^{\mathrm{a}}$ \\
Double emulsion & $80.0 \pm 0.9^{\mathrm{c}}$ & $0.141 \pm 0.002^{\mathrm{b}}$ & $0.70 \pm 0.02^{\mathrm{b}}$ & $11.2^{\mathrm{a}} \pm 0.1^{\mathrm{a}}$ & $8.0 \pm 0.5^{\mathrm{b}}$ \\
\hline Milk (control) & $86.3 \pm 0.2^{\mathrm{b}}$ & $0.75 \pm 0.02^{\mathrm{a}}$ & $3.72 \pm 0.06^{\mathrm{a}}$ & $1.01 \pm 0.05^{\mathrm{b}}$ & $7.6 \pm 0.2^{\mathrm{a}}$ \\
Extract & $88.0 \pm 0.3^{\mathrm{a}}$ & $0.78 \pm 0.03^{\mathrm{a}}$ & $3.7 \pm 0.1^{\mathrm{a}}$ & $0.97 \pm 0.03^{\mathrm{b}}$ & $6.0 \pm 0.3^{\mathrm{b}}$ \\
Double emulsion & $83.7 \pm 0.8^{\mathrm{c}}$ & $0.77 \pm 0.04^{\mathrm{a}}$ & $2.39 \pm 0.07^{\mathrm{b}}$ & $11.2 \pm 0.3^{\mathrm{a}}$ & $2.5 \pm 0.1^{\mathrm{c}}$ \\
\hline Soy (control) & $92.40 \pm 0.08^{\mathrm{a}}$ & $0.5 \pm 0.1^{\mathrm{a}}$ & $3.4 \pm 0.1^{\mathrm{a}}$ & $2.1 \pm 0.1^{\mathrm{b}}$ & $1.6 \pm 0.1^{\mathrm{a}}$ \\
Extract & $92.3 \pm 0.3^{\mathrm{a}}$ & $0.56 \pm 0.02^{\mathrm{a}}$ & $3.40 \pm 0.02^{\mathrm{a}}$ & $2.09 \pm 0.05^{\mathrm{b}}$ & $1.7 \pm 0.2^{\mathrm{a}}$ \\
Double emulsion & $83.9 \pm 0.2^{\mathrm{b}}$ & $0.49 \pm 0.01^{\mathrm{b}}$ & $2.48 \pm 0.02^{\mathrm{b}}$ & $12.4 \pm 0.1^{\mathrm{a}}$ & $0.9 \pm 0.1^{\mathrm{b}}$ \\
\hline
\end{tabular}

Results are presented as mean \pm standard deviation. Different letters correspond to significant differences $(p$-value $<0.05)$.

The impact of the double emulsion coloring system on the fatty acids relative composition (expressed as SFA, MUFA, and PUFA) can be perceived by analyzing the data listed in Table 5. The detailed analysis in terms of fatty acid compositions can be found in Table S1 provided in the Supplementary Materials. In summary, for yoghurt and milk, an increase in MUFA and PUFA and a decrease in SFA were observed, whereas for the rice drink a maintenance of SFA, an increase in PUFA and a decrease in MUFA resulted. For soy drink, which is already characterized by a high PUFA content [35], an increase in MUFA and decreases in both SFA and PUFA were registered. In general, the unsaturated fatty acids content is strongly related to the oil composition [36-38]. This is particularly valid for foods with low lipid contents as was the case with the chosen food matrices. All the 
samples containing the double emulsion presented values of PUFA/SFA ratio above the recommended by Food and Agriculture Organization of the United Nations (FAO) \& World Health Organization (WHO) [39] (higher than 0.45), which can be considered favorable. Thus, these formulations can benefit from introducing healthy oils, e.g., sesame, flaxseed, and avocado oil, which, apart from having high unsaturated fatty acids content, can present vitamins and antioxidants (the concentration will be conditioned by the extraction method). Moreover, the developed coloring solution can result in a very appropriate alternative for high lipid content foods (e.g., mayonnaise).

Table 5. Fatty acids composition, expressed as SFA, MUFA, and PUFA, of the studied base food matrices (control) and respective colored systems (with extract or double emulsion) (mean $\pm \mathrm{SD}$, $n=9)$.

\begin{tabular}{cccc}
\hline \multirow{2}{*}{ Fatty Acids (\%) } & \multicolumn{3}{c}{ Yogurt } \\
\cline { 2 - 4 } & Base Drink & Extract & Double Emulsion \\
\hline SFA & $73.7 \pm 0.9^{\mathrm{a}}$ & $73.6 \pm 0.2^{\mathrm{a}}$ & $16.1 \pm 0.3^{\mathrm{b}}$ \\
MUFA & $21.3 \pm 0.7^{\mathrm{a}}$ & $21.7 \pm 0.1^{\mathrm{a}}$ & $33.3 \pm 0.5^{\mathrm{b}}$ \\
PUFA & $5.0 \pm 0.2^{\mathrm{b}}$ & $4.7 \pm 0.1^{\mathrm{b}}$ & $50.6 \pm 0.2^{\mathrm{a}}$ \\
\hline \multicolumn{4}{c}{ Rice } \\
\hline SFA & $18.1 \pm 0.2^{\mathrm{a}}$ & $14.3 \pm 0.1^{\mathrm{c}}$ & $15.10 \pm 0.01^{\mathrm{b}}$ \\
MUFA & $71.7 \pm 0.2^{\mathrm{a}}$ & $72.4 \pm 0.1^{\mathrm{a}}$ & $36.9 \pm 0.5^{\mathrm{b}}$ \\
PUFA & $10.2 \pm 0.1^{\mathrm{c}}$ & $13.24 \pm 0.02^{\mathrm{b}}$ & $48.0 \pm 0.5^{\mathrm{a}}$ \\
\hline & & Milk \\
\hline SFA & $74.6 \pm 0.2^{\mathrm{a}}$ & $73.8 \pm 0.1^{\mathrm{a}}$ & $23.1 \pm 0.3^{\mathrm{b}}$ \\
MUFA & $22.3 \pm 0.3^{\mathrm{c}}$ & $23.49 \pm 0.04^{\mathrm{b}}$ & $32.2 \pm 0.4^{\mathrm{a}}$ \\
PUFA & $3.08 \pm 0.06^{\mathrm{b}}$ & $2.7 \pm 0.1^{\mathrm{b}}$ & $44.7 \pm 0.7^{\mathrm{a}}$ \\
\hline & & Soy & \\
\hline SFA & $20.8 \pm 0.5^{\mathrm{a}}$ & $20.33 \pm 0.07^{\mathrm{a}}$ & $15.7 \pm 0.5^{\mathrm{b}}$ \\
MUFA & $20.6 \pm 0.4^{\mathrm{b}}$ & $20.48 \pm 0.09^{\mathrm{b}}$ & $31.4 \pm 0.3^{\mathrm{a}}$ \\
PUFA & $58.6 \pm 0.9^{\mathrm{a}}$ & $59.15 \pm 0.02^{\mathrm{a}}$ & $52.9 \pm 0.8^{\mathrm{b}}$ \\
\hline
\end{tabular}

Results are presented as mean \pm standard deviation. Different letters correspond to significant differences ( $p$-value $<0.05)$. SFA: saturated fatty acids; MUFA: monounsaturated fatty acids; PUFA: polyunsaturated fatty acids.

\section{Materials and Methods}

\subsection{Materials}

The emulsifier polyglycerol polyricinoleate (PGPR, HLB 1.5) was acquired from Palsgaard (Palsgaardvej, Juelsminde, Denmark), Polysorbate 80 (Tween 80, HLB 15), Alfa Aesar L13315, obtained from Alfa Aesar (Karlsruhe, Germany), and gum Arabic from acacia, Fisher Chemical G/1050/53, provided from Fisher Scientific UK (Loughborough, England). Corn oil (brand Fula) and the food matrices (natural yoghurt with $0 \%$ fat (brand Skyr), rice drink (brand Continente Bio), cow milk (brand Continente), and soy drink (brand Continente Bio) were purchased from a local supermarket at Bragança (Portugal).

Sulfuric acid, toluene, methanol, ethyl ether, and the remaining analytical grade chemical reagents were obtained from current suppliers. The standard mixture with 37 fatty acid methyl esters (FAME) (reference 47885-U) was purchased from Sigma (St. Louis, MO, USA).

The Sambucus nigra L. extract was obtained by grinding the fruit in a juicer. The extract was centrifuged at $10,000 \mathrm{rpm}$ for $10 \mathrm{~min}$ at $10^{\circ} \mathrm{C}$ and then vacuum filtered. The juice was spray-dried to obtain the extract in powdered form (Mini Spray Dryer B290 Büchi, Flawil, Switzerland) using an inlet temperature of $130{ }^{\circ} \mathrm{C}, 90 \%$ aspiration, $667 \mathrm{~L} / \mathrm{h}$ of atomizing airflow, and $12 \mathrm{~mL} / \mathrm{min}$ inlet feed rate. The powder extract was stored under refrigerated for subsequent use. The mature fruits of Sambucus nigra L. were collected in the Natural Park of Montesinho territory, Trás-os-Montes, north-eastern Portugal. 


\subsection{Preparation and Characterization of the Double Emulsions}

The double emulsions were prepared in a two-step procedure. Firstly, a primary emulsion $(\mathrm{W} 1 / \mathrm{O})$ was made using a $\mathrm{W} / \mathrm{O}$ ratio of $40 / 60(v / v)$. The aqueous phase was an elderberry extract solution $(55 \mathrm{~g} / \mathrm{L})$ added with $5 \%(w / w)$ of PGPR and the oil-phase corn oil. The emulsion was homogenized using an Ultra-Turrax (Unidrive X1000 Homogeneizer Drive-CAT Scientific, Staufen, Germany) at $20000 \mathrm{rpm}$ for $5 \mathrm{~min}$. In a second step the $\mathrm{W} 1 / \mathrm{O}$ emulsion was dispersed into the second aqueous phase (W2) to form the double emulsion (W1/O/W2). Different (W1/O)/W2 ratios ( $v / v)$ were used, namely 20/80, 30/70, $40 / 60$, and $50 / 50(v / v)$. The W2 aqueous phase comprised $3 \%$ of Tween $80(w / w$, total emulsion-basis) and 15\% gum Arabic ( $w / w$, W2-basis). The mixture was homogenized using the aforementioned Ultra-Turrax system at $6000 \mathrm{rpm}$ for $2 \mathrm{~min}$.

To select the most stable double emulsion to proceed with their use as coloring agents and testing in food matrices, the prepared emulsions were characterized by optical microscopy and using the cream index methodology.

The emulsion morphology and droplet size were evaluated immediately after the emulsion production and monitored after 5 and 20 days to check for the occurrence of destabilization phenomena. The used apparatus was a Nikon Eclipse 50i microscope (Tokyo, Japan) equipped with a Nikon Digital and NIS-Elements Documentation software. For the analysis, an aliquot of the sample was placed on a slide and gently covered with a coverslip.

The creaming index was evaluated at different time intervals $(0,5,10$, and 20 days $)$ following the methodology described by Choudhary et al. [40] with minor adaptations. Briefly, the emulsions were stored in graduated cylinders of $50 \mathrm{~mL}$ at $23 \pm 2{ }^{\circ} \mathrm{C}$. The "creaming index" (CI, \%) was calculated using Equation (1), where HS and HT were the serum layer and total emulsion height, respectively, expressed in $\mathrm{cm}$.

$$
C I(\%)=\frac{H S}{H T}
$$

\subsection{Preparation and Characterization of the Colored Food Products}

The most stable emulsion was used as a coloring agent in food matrices selected to cover a $\mathrm{pH}$ range from acidic to basic (natural yogurt with $0 \%$ fat $(\mathrm{pH} 4.65)$, rice drink $(\mathrm{pH}$ 6.01), cow milk ( $\mathrm{pH}$ 6.47), and soy drink ( $\mathrm{pH} 7.92)$ ) and compared with the direct use of the extract at the same concentration. The $\mathrm{pH}$ of the food matrices was determined using the PH-meter InoLab 720 (pH Meter InoLab pH 720, Weilheim, Germany) at room temperature. The used emulsion amount was calculated to achieve an elderberry extract concentration of $4 \mathrm{~g} / \mathrm{L}$ in the food product (the same used for the free extract). Two temperatures were selected: $23 \pm 2{ }^{\circ} \mathrm{C}$ (room temperature) and $4 \pm 2{ }^{\circ} \mathrm{C}$ (refrigeration temperature).

The color of the food products (natural yoghurt, rice, cow milk, and soy drinks) added with the emulsion or directly with the extract was measured with the colorimeter (model CR-400, Konica Minolta Sensing Inc., Sakai-ku, Japan) at 0, 3, and 7 days after preparation. Values of $\mathrm{L}^{*}$ (lightness), $\mathrm{a}$ * (red to green), and $\mathrm{b}$ * (blue to yellow) were obtained. From these data, $\Delta \mathrm{E}$ values were calculated from Equation (2), where $\Delta \mathrm{L}, \Delta \mathrm{a}$, and $\Delta \mathrm{b}$ represent the differences between the color of the sample and the control (food product with no addition of a colorant system).

$$
\Delta E=\sqrt{(\Delta L)^{2}+(\Delta a)^{2}+(\Delta b)^{2}}
$$

\subsection{Statistical Analysis}

For each tested food product (natural yoghurt, rice, cow milk, and soy drinks), three independent samples were analyzed, and three sequential readings of $\mathrm{L}^{*}, \mathrm{a}^{*}$, and $\mathrm{b}^{*}$ were performed in each sample. The data were expressed as a mean \pm standard deviation (SD). The statistical tests were applied considering a value of $\alpha=0.05$ (5\% significance level), 
using the IBM SPSS Statistics for Windows software, version 25.0. (International Business Machines Corporation. Armonk, New York, USA).

The analysis of variance (ANOVA) was performed with a type III sum of squares, using the generalized linear model (GLM) procedure. All dependent variables were analyzed using 2-way ANOVA, considering formulation type (FT: extract, double emulsion) and storage time (ST: 0, 3, 7 days) as variability factors. Once there was a significant interaction between the two factors in all cases, the results were compared using the graphs of the estimated marginal means. Compliance with ANOVA requirements, specifically the normal distribution of results and the homogeneity of variances, was verified using the ShapiroWilk and Levene's test, respectively.

Moreover, a linear discriminant analysis (LDA) was used to globally characterize the effect of different FT and ST over the tested food products. The variables were selected sequentially (stepwise), considering the Wilks' $\Lambda$ test with the usual $F$ probabilities (3.84 to enter and 2.71 to remove). The main objective was to estimate the relationship between the dependent categorical variables (food products or storage times) with the quantitative independent variables (results obtained for the colorimetric parameters). An internal cross-validation procedure was applied to assess the performance and adequacy of the discriminant model.

\subsection{Proximal Composition and Fatty Acids Determination of Base and Colored Foods}

The proximal composition (moisture, ash, proteins, lipids, and carbohydrates) was evaluated according to official food analysis methods described by the AOAC [41]. Results were presented in $\mathrm{g} / 100 \mathrm{~mL}$ in all cases. Fatty acids were determined by gas chromatography with flame ionization detection (GC-FID) according to the methodology described by Barros et al. [42]. Results were presented in $\mathrm{g} / 100 \mathrm{~mL}$ in all cases. Fatty acids are expressed as relative percentage of each fatty acid. All experiments were performed in triplicate. ANOVA test was used to analyze the data to determine if the differences between the samples are significant $(p$-value $<0.05)$.

\section{Conclusions}

In the present study, a coloring agent based on a double emulsion system was developed, aiming at protecting Sambucus nigra L. coloring extract, thus minimizing the typical color variability of anthocyanins with $\mathrm{pH}$. The best-developed formulation corresponds to the double emulsion using a 50/50 (W1/O)/W2 ratio prepared from a primary emulsion comprising a $40 / 60 \mathrm{~W} / \mathrm{O}$ ratio. When incorporated into food matrices, this coloring agent resulted in systems with higher stability over time, providing a better color uniformity across the tested $\mathrm{pH}$. The concept was demonstrated by performing the proof of concept with real food matrices showing the advantages, but also evidencing some potential constraints, namely the impact on the nutritional composition of the final product. Future work will consider further optimization of oil and colorant content (to decrease the impact of oil in the proximal composition of the final products and improve color intensity) and testing with other food matrices, namely foods with different nutritional composition, including lipid-rich matrices. Furthermore, the stability of the double emulsions in the food matrices should be examined for a prolonged time to verify the usability and marketability of the developed product. Additionally, sensory analysis is an important step to follow with the focus on organoleptic properties of the product, namely texture, color, and odor.

Supplementary Materials: The following is available online. Table S1. Fatty acids composition of the studied base food matrices and respective colored products.

Author Contributions: Conceptualization, L.G.T., M.-F.B. and I.C.F.R.F.; methodology, L.G.T., S.R., I.P.F., Â.F., J.C.M.B. and L.B.; formal analysis, L.G.T. and J.C.M.B..; investigation, L.G.T., S.R., I.P.F., Â.F., J.C.M.B. and L.B.; resources, M.-F.B. and I.C.F.R.F.; data curation, L.G.T., S.R. and L.B.; writingoriginal draft preparation, L.G.T., S.R. and J.C.M.B.; writing—review and editing, M.-F.B.; supervision, 
M.-F.B., F.V.L. and I.C.F.R.F.; funding acquisition, M.-F.B. and I.C.F.R.F. All authors have read and agreed to the published version of the manuscript.

Funding: FCT/MCTES for financial support to CIMO (UIDB/00690/2020). National funding by FCTFoundation for Science and Technology, through the institutional scientific employment programcontract of A. Fernandes, I. Fernandes, and L. Barros. Valor Natural project (Project Norte-01-0247FEDER-024479).

Conflicts of Interest: The authors declare no conflict of interest.

Sample Availability: Samples of the compounds are not available from the authors.

\section{References}

1. Ulbricht, C.; Basch, E.; Cheung, L.; Goldberg, H.; Hammerness, P.; Isaac, R.; Khalsa, K.P.S.; Romm, A.; Rychlik, I.; Varghese, M.; et al. An evidence-based systematic review of elderberry and elderflower (Sambucus nigra) by the natural standard research collaboration. J. Diet. Suppl. 2014, 11, 80-120. [CrossRef] [PubMed]

2. $\quad$ Rodrigues, S.; de Brito, E.S.; de Oliveira Silva, E. Elderberry—Sambucus nigra L. In Exotic Fruits; Elsevier: London, UK, 2018; ISBN 9780128031384

3. Albuquerque, B.R.; Pinela, J.; Barros, L.; Oliveira, M.B.P.P.; Ferreira, I.C.F.R. Anthocyanin-rich extract of jabuticaba epicarp as a natural colorant: Optimization of heat- and ultrasound-assisted extractions and application in a bakery product. Food Chem. 2020, 316, 126364. [CrossRef] [PubMed]

4. Młynarczyk, K.; Walkowiak-Tomczak, D.; Łysiak, G.P. Bioactive properties of Sambucus nigra L. as a functional ingredient for food and pharmaceutical industry. J. Funct. Foods 2018, 40, 377-390. [CrossRef] [PubMed]

5. $\quad$ Domínguez, R.; Zhang, L.; Rocchetti, G.; Lucini, L.; Pateiro, M.; Munekata, P.E.S.; Lorenzo, J.M. Elderberry (Sambucus nigra L.) as potential source of antioxidants. Characterization, optimization of extraction parameters and bioactive properties. Food Chem. 2020, 330, 127266. [CrossRef]

6. Senica, M.; Stampar, F.; Veberic, R.; Mikulic-Petkovsek, M. Processed elderberry (Sambucus nigra L.) products: A beneficial or harmful food alternative? LWT-Food Sci. Technol. 2016, 72, 182-188. [CrossRef]

7. Shaddel, R.; Hesari, J.; Azadmard-Damirchi, S.; Hamishehkar, H.; Fathi-Achachlouei, B.; Huang, Q. Double emulsion followed by complex coacervation as a promising method for protection of black raspberry anthocyanins. Food Hydrocoll. 2018, 77, 803-816. [CrossRef]

8. Zeng, Y.J.; Xu, P.; Yang, H.R.; Zong, M.H.; Lou, W.Y. Purification of anthocyanins from saskatoon berries and their microencapsulation in deep eutectic solvents. LWT-Food Sci. Technol. 2018, 95, 316-325. [CrossRef]

9. Smeriglio, A.; Barreca, D.; Bellocco, E.; Trombetta, D. Chemistry, Pharmacology and Health Benefits of Anthocyanins. Phyther. Res. 2016, 30, 1265-1286. [CrossRef]

10. Silva, P.I.; Stringheta, P.C.; Teófilo, R.F.; Oliveira, I.R.N. Parameter optimization for spray-drying microencapsulation of jaboticaba (Myrciaria jaboticaba) peel extracts using simultaneous analysis of responses. J. Food Eng. 2013, 117, 538-544. [CrossRef]

11. Das, A.B.; Goud, V.V.V.; Das, C. Microencapsulation of anthocyanin extract from purple rice bran using modified rice starch and its effect on rice dough rheology. Int. J. Biol. Macromol. 2019, 124, 573-581. [CrossRef]

12. Sánchez-Madrigal, M.; Quintero-Ramos, A.; Amaya-Guerra, C.A.; Meléndez-Pizarro, C.O.; Castillo-Hernández, S.L.; AguileraGonzález, C.J. Effect of Agave Fructans as Carrier on the Encapsulation of Blue Corn Anthocyanins by Spray Drying. Foods 2019, 8, 268. [CrossRef]

13. Eisinaité, V.; Leskauskaité, D.; Pukalskiené, M.; Venskutonis, P.R. Freeze-drying of black chokeberry pomace extract-loaded double emulsions to obtain dispersible powders. J. Food Sci. 2020, 85, 628-638. [CrossRef] [PubMed]

14. Mahdavee Khazaei, K.; Jafari, S.M.; Ghorbani, M.; Hemmati Kakhki, A. Application of maltodextrin and gum Arabic in microencapsulation of saffron petal's anthocyanins and evaluating their storage stability and color. Carbohydr. Polym. 2014, 105, 57-62. [CrossRef]

15. Yu, Y.; Lv, Y. Degradation kinetic of anthocyanins from rose (Rosa rugosa) as prepared by microencapsulation in freeze-drying and spray-drying. Int. J. Food Prop. 2019, 22, 2009-2021. [CrossRef]

16. Chen, B.H.; Inbaraj, B.S. Nanoemulsion and nanoliposome based strategies for improving anthocyanin stability and bioavailability. Nutrients 2019, 11, 1052. [CrossRef] [PubMed]

17. Bryła, A.; Lewandowicz, G.; Juzwa, W. Encapsulation of elderberry extract into phospholipid nanoparticles. J. Food Eng. 2015, 167, 189-195. [CrossRef]

18. Zhao, L.; Temelli, F.; Chen, L. Encapsulation of anthocyanin in liposomes using supercritical carbon dioxide: Effects of anthocyanin and sterol concentrations. J. Funct. Foods 2017, 34, 159-167. [CrossRef]

19. Nguyen, T.T.; Phan-Thi, H.; Pham-Hoang, B.N.; Ho, P.T.; Tran, T.T.T.; Waché, Y. Encapsulation of Hibiscus sabdariffa L. anthocyanins as natural colours in yeast. Food Res. Int. 2018, 107, 275-280. [CrossRef]

20. Rabelo, C.A.S.; Taarji, N.; Khalid, N.; Kobayashi, I.; Nakajima, M.; Neves, M.A. Formulation and characterization of water-in-oil nanoemulsions loaded with açaí berry anthocyanins: Insights of degradation kinetics and stability evaluation of anthocyanins and nanoemulsions. Food Res. Int. 2018, 106, 542-548. [CrossRef] 
21. Ishkeh, S.R.; Shirzad, H.; Asghari, M.R.; Alirezalu, A.; Pateiro, M.; Lorenzo, J.M. Effect of Chitosan Nanoemulsion on Enhancing the Phytochemical Contents, Health-Promoting Components, and Shelf Life of Raspberry (Rubus sanctus Schreber). Appl. Sci. 2021, 11, 2224. [CrossRef]

22. Bamba, B.; Shi, J.; Tranchant, C.; Xue, S.; Forney, C.; Lim, L.-T.; Xu, W.; Xu, G. Coencapsulation of Polyphenols and Anthocyanins from Blueberry Pomace by Double Emulsion Stabilized by Whey Proteins: Effect of Homogenization Parameters. Molecules 2018, 23, 2525. [CrossRef] [PubMed]

23. Frank, K.; Walz, E.; Gräf, V.; Greiner, R.; Köhler, K.; Schuchmann, H.P. Stability of Anthocyanin-Rich W/O/W-Emulsions Designed for Intestinal Release in Gastrointestinal Environment. J. Food Sci. 2012, 77, 50-57. [CrossRef] [PubMed]

24. De Moura, S.C.S.R.; Berling, C.L.; Germer, S.P.M.; Alvim, I.D.; Hubinger, M.D. Encapsulating anthocyanins from Hibiscus sabdariffa L. calyces by ionic gelation: Pigment stability during storage of microparticles. Food Chem. 2018, 241, 317-327. [CrossRef] [PubMed]

25. Lin, X.; Li, S.; Yin, J.; Chang, F.; Wang, C.; He, X.; Huang, Q.; Zhang, B. Anthocyanin-loaded double Pickering emulsion stabilized by octenylsuccinate quinoa starch: Preparation, stability and in vitro gastrointestinal digestion. Int. J. Biol. Macromol. 2020, 152, 1233-1241. [CrossRef]

26. Huang, Y.; Zhou, W. Microencapsulation of anthocyanins through two-step emulsification and release characteristics during in vitro digestion. Food Chem. 2019, 278, 357-363. [CrossRef]

27. Diep, T.T.; Dao, T.P.; Vu, H.T.; Phan, B.Q.; Ngoc, D.; Bui, T.H.; Truong, V.; Nguyen, V. Double emulsion oil-in water-in oil (O/W/O) stabilized by sodium caseinate and k-carrageenan. J. Dispers. Sci. Technol. 2018, 39, 1752-1757. [CrossRef]

28. Liu, J.; Zhou, H.; Mundo, J.L.M.; Tan, Y.; Pham, H.; Mcclements, D.J. Fabrication and characterization of W/O/W emulsions with crystalline lipid phase. J. Food Eng. 2020, 273, 1-12. [CrossRef]

29. Liu, J.; Tan, Y.; Zhou, H.; Muriel Mundo, J.L.; McClements, D.J. Protection of anthocyanin-rich extract from pH-induced color changes using water-in-oil-in-water emulsions. J. Food Eng. 2019, 254, 1-9. [CrossRef]

30. Shaddel, R.; Hesari, J.; Azadmard-Damirchi, S.; Hamishehkar, H.; Fathi-Achachlouei, B.; Huang, Q. Use of gelatin and gum Arabic for encapsulation of black raspberry anthocyanins by complex coacervation. Int. J. Biol. Macromol. 2018, 107, 1800-1810. [CrossRef]

31. Ding, S.; Serra, C.A.; Vandamme, T.F.; Yu, W.; Anton, N. Double emulsions prepared by two-step emulsification: History, state-of-the-art and perspective. J. Control. Release 2019, 295, 31-49. [CrossRef]

32. Almeida Paula, D.; Mota Ramos, A.; Basílio de Oliveira, E.; Maurício Furtado Martins, E.; Augusto Ribeiro de Barros, F.; Cristina Teixeira Ribeiro Vidigal, M.; de Almeida Costa, N.; Tatagiba da Rocha, C. Increased thermal stability of anthocyanins at pH 4.0 by guar gum in aqueous dispersions and in double emulsions W/O/W. Int. J. Biol. Macromol. 2018, 117, 665-672. [CrossRef]

33. Xiao, J.; Lu, X.; Huang, Q. Double emulsion derived from kafirin nanoparticles stabilized Pickering emulsion: Fabrication, microstructure, stability and in vitro digestion profile. Food Hydrocoll. 2017, 62, 230-238. [CrossRef]

34. Gharehbeglou, P.; Jafari, S.M.; Hamishekar, H.; Homayouni, A.; Mirzaei, H. Pectin-whey protein complexes vs. small molecule surfactants for stabilization of double nano-emulsions as novel bioactive delivery systems. J. Food Eng. 2019, 245, 139-148. [CrossRef]

35. Ivanov, D.S.; Lević, J.D.; Sredanović, S.A. Fatty acid composition of various soybean products. Food Feed Res. 2010, 2, 65-70.

36. Muguerza, E.; Ansorena, D.; Astiasarán, I. Improvement of nutritional properties of Chorizo de Pamplona by replacement of pork backfat with soy oil. Meat Sci. 2003, 65, 1361-1367. [CrossRef]

37. Orsavova, J.; Misurcova, L.; Ambrozova, J.V.; Vicha, R.; Mlcek, J. Fatty acids composition of vegetable oils and its contribution to dietary energy intake and dependence of cardiovascular mortality on dietary intake of fatty acids. Int. J. Mol. Sci. 2015, 16, 12871-12890. [CrossRef] [PubMed]

38. Yang, R.; Zhang, L.; Li, P.; Yu, L.; Mao, J.; Wang, X.; Zhang, Q. A review of chemical composition and nutritional properties of minor vegetable oils in China. Trends Food Sci. Technol. 2018, 74, 26-32. [CrossRef]

39. FAO-WHO. Fats and Fatty Acids in Human Nutrition: Report of an Expert Consultation; FAO-WHO: Geneva, Switzerland, 2010; pp. 1-166. ISSN 0254-4725.

40. Choudhary, U.; Sabikhi, L.; Abdul Hussain, S.; Khamrui, K.; Sharma, V.; Vij, S. Stabilizing the primary emulsion with hydrophobic emulsifiers and salt for encapsulating herbal extracts in a double emulsion. J. Food Process. Preserv. 2018, 42, 1-9. [CrossRef]

41. AOAC. Official methods of analysis of AOAC international. In Association of Official Analytical Chemists, 20th ed.; AOAC INTERNATIONAL: Rockville, MA, USA, 2016; pp. 1-3172.

42. Barros, L.; Pereira, E.; Calhelha, R.C.; Dueñas, M.; Carvalho, A.M.; Santos-buelga, C.; Ferreira, I.C.F.R.F.R. Bioactivity and chemical characterization in hydrophilic and lipophilic compounds of Chenopodium ambrosioides L. J. Funct. Foods 2013, 5, 1732-1740. [CrossRef] 